\title{
BLADDER CANCER AFTER SPINAL CORD INJURY
}

\author{
Incidence, presentation, histology and prognosis compared with
} bladder cancer in the non-paralysed population.

By W. S. El-Masri, M.B., B.Ch., F.R.C.S.(Ed.) and G. Fellows, M.S., F.R.C.S. National Spinal Injuries Centre, Stoke Mandeville Hospital, Aylesbury, Bucks, England.

Abstract. We reviewed 25 patients who developed carcinoma of the bladder following spinal cord injury among a series of 6744 paraplegic and tetraplegic patients.

An analysis of the incidence, presentation, possible predisposing pactors and prognosis was carried out. The majority presented at a younger age and there was a significantly higher incidence of squamous carcinoma than in the non-paraplegic population. The anterior bladder wall was involved in about 25 per cent of the cases. The prognosis is poor.

Key words: Spinal injuries; Carcinoma of the bladder.

\section{Introduction}

KAWAICHI in I96I reported four cases of carcinoma of the bladder in a series of I600 spinal cord injury patients. Melzak in I966 found I I patients with carcinoma of the bladder in a series of 3800 spinal cord injury patients. It appeared then that there was an unexpected higher number of bladder tumours in these patients and the prognosis was poor. He suggested that patients with flaccid bladders are more prone to developing carcinoma of the bladder.

Turner (I980) reviewed carcinoma of the bladder in patients with all types of neuropathic bladder. He found that 50 per cent were squamous.

\section{Material}

This paper updates Melzak's study of patients at the National Spinal Injuries Centre, Stoke Mandeville Hospital.

Twenty-five patients with carcinoma of the bladder were found in the histology records in a series of 6744 spinal cord injury patients at Stoke Mandeville Hospital. Eleven of these patients were described by Melzak in 1966.

\section{Incidence and Mortality}

All except four patients have died of their bladder tumours. The death rate of carcinoma of the bladder in the male population in England and Wales is 7.4/100 000. A calculation, taking into consideration the age and sex distribution and length of observation of the 6744 patients with spinal cord injury, gives an expected total of I.I deaths from carcinoma of the bladder. We recorded 2I deaths. Cord injury increased the risk of dying of bladder cancer by a factor of about $20 .^{1}$

1 We are indebted to Dr K. McPherson, Department of Social and Community Medicine, University of Oxford, Oxford, for the calculations. 
Neurology

Twelve patients had upper motor neurone spastic lesions and another I2 patients had lower motor neurone flaccid lesions while the neurology of one patient was unrecorded.

\section{Age at Diagnosis}

It appears that patients with spinal cord injuries develop their tumours at a younger age than in the general population (Table I). A quarter of the patients were under the age of 40 compared with 3 per cent of patients with bladder cancer in the general population, according to the Bristol Bladder Tumour Registry. Carcinoma of the bladder appears to be one of the long term complications of spinal cord injury or its management. The interval between injury and diagnosis varied between I I and 42 years with a mean of 23 years. We have excluded one patient with a non-invasive transitional cell carcinoma diagnosed 2 months after injury.

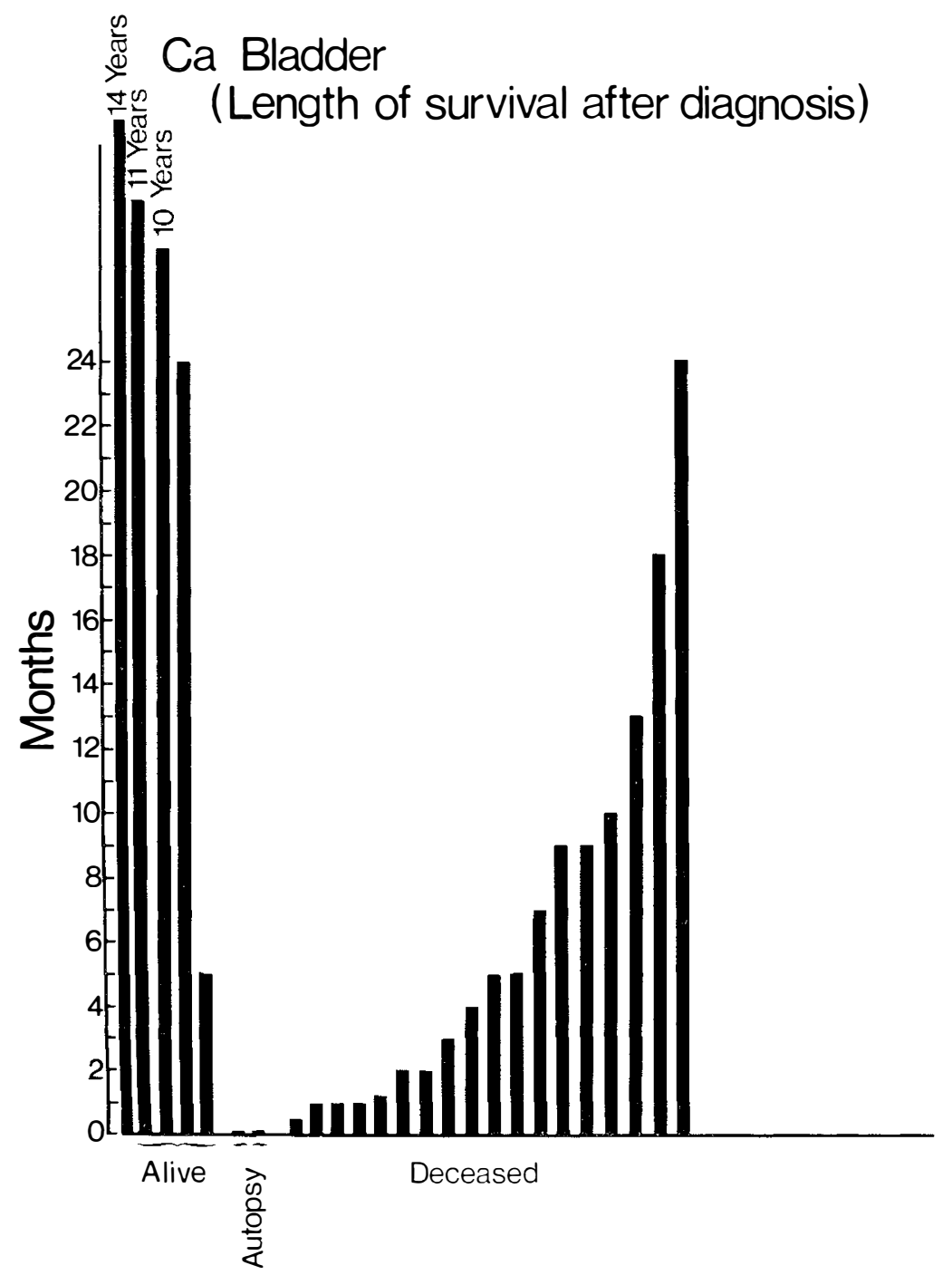

FIG. I. 
TABLE I

Age at diagnosis

\begin{tabular}{|c|c|c|c|c|c|c|c|c|}
\hline & $<20$ & $20-29$ & $30-39$ & $4^{C}-49$ & $50-59$ & $60-69$ & $70-79$ & $80+$ \\
\hline Bristol & 2 & 6 & $\begin{array}{c}37 \\
2.7 \%\end{array}$ & 109 & 297 & 460 & 374 & 94 \\
\hline $\begin{array}{l}\text { S.M.H. } \\
\text { N.S.I.C. }\end{array}$ & 0 & 0 & $\begin{array}{c}6 \\
24 \%\end{array}$ & 4 & IO & 5 & 0 & 0 \\
\hline
\end{tabular}

Interval between injury and diagnosis

$$
\begin{array}{r}
\text { I I }-42 \text { years } \\
\text { Mean } 23 \text { years }
\end{array}
$$

Excluding non-invasive T.C.C. at 2 months

Year of Injury

It appears that the majority of patients were iniured between I940-49 (Table II). This incidence may be related to the original management of the neuropathic bladder in this decade, many patients being treated with suprapubic cystotomy.

\section{TABLE II}

Year of injury

\begin{tabular}{cccccccc}
\hline Before I940 & $40-44$ & $45-49$ & $50-54$ & $55-59$ & $60-64$ & $65-70$ \\
\hline No. & 3 & 8 & 6 & 2 & 0 & 0 & I \\
\hline
\end{tabular}

Unknown 4

\section{Clinical Presentation}

The commonest presenting symptom was haematuria (Table III). Haematuria, however, is a common symptom in patients with a neuropathic bladder, because of infection or catheter trauma.

\section{TABLE III}

Presenting symptoms

\begin{tabular}{lr}
\hline Haematuria & I5 \\
Frequency/Dirty urine & 5 \\
Bladder pain & 4 \\
Suprapubic mass or discharge & 3 \\
Difficulty voiding & 2 \\
Sweating & I \\
Metastases & I \\
No data & I \\
Diagnosed at autopsy & 2 \\
\hline
\end{tabular}


All these patients had clinically infected urine. Fifteen patients were treated initially with suprapubic catheters. Eight patients were subsequently treated with an indwelling urethral catheter.

Bladder stones were found and removed from I I patients. However, two patients were initially treated with intermittent catheterisation and had no bladder stones at any time.

TABLE IV

Possible predisposing factors

\begin{tabular}{|c|c|c|c|}
\hline & Yes & No & $?$ \\
\hline Initial suprapubic catheters-Cystotomy & I 5 & 5 & 5 \\
\hline Subsequent urethral catheters & 8 & 14 & I \\
\hline Bladder stones & II & II & 3 \\
\hline
\end{tabular}

No suprapubic catheters

No indwelling urethral catheters 2

Site of the Tumour (Table V)

Lateral wall tumours were found in seven patients. Six patients were found to have anterior wall tumours, three of which arose in the track of a suprapubic cystotomy. Tumours widespread throughout the bladder were found in five patients. Three tumours were found in the base of the bladder and the bladder neck. In four the site was not recorded.

TABLE V

Site of tumour

\begin{tabular}{ll}
\hline Lateral wall & 7 \\
Anterior wall & 6 (S.P. Track in 3) \\
Throughout & 5 \\
Base and bladder neck & 3 \\
Unknown & 4 \\
\hline
\end{tabular}

TABLE VI

Histology

\begin{tabular}{lll}
\hline & Bristol & S.M.H. \\
\hline Papilloma & 26 & O \\
Transitional C.C. & I379 & I3 $(5$ partly squamous $)$ \\
Squamous C.C. & $24(\mathrm{I} \cdot 6 \%)$ & I I $(44 \%)$ \\
Adeno carcinoma & 3 & 0 \\
Not known & 68 & 0 \\
Undifferentiated & 0 & I \\
\hline & Invasive & 22 \\
& Non invasive & I \\
& Not known & 2
\end{tabular}




\section{Histology (Table VI)}

Eleven of these tumours (44 per cent) were of the squamous cell type and one was undifferentiated. Five of the remaining 13 transitional cell tumours were also partly squamous. Most of these tumours were invasive (22), one was non-invasive and the information could not be retrieved in two.

\section{Survival}

Generally these are fatal tumours whichever way they are treated and 20 out of the 25 patients were dead within two years of the diagnosis. There were four longterm survivors (6, IO, I I and I4 years), three were squamous and were treated with radiotherapy only; one was transitional and was treated with cystectomy and radiotherapy.

\section{Discussion}

Patients with spinal cord injuries are more prone to develop carcinoma of the bladder than the general population. None of the patients was engaged in an occupation with a high risk of bladder cancer.

The number of patients with spasticity below the level of their lesions equalled those with flaccidity, hence we do not agree with Melzak that flaccid, non-contractable bladders are at higher risk than spastic ones. Tumour formation may not be peculiar to spinal cord injury patients alone and we expect that patients with neuropathic bladders due to other aetiology than trauma may share the same risk, as suggested by Turner and Davies.

There was a statistically significant difference in the percentage of patients who presented under the age of 40 ( 24 per cent in the spinal cord injury population), compared with 3 per cent in the general population.

Fifteen patients were treated initially with suprapubic catheters for periods varying between I month and 25 years. Twenty patients had an indwelling catheter for varying periods of 2 months to 5 years. Suprapubic catheters, cystostomy and indwelling urethral catheters were the primary line of management available before 1950. Seventeen out of the 25 patients were injured during this period and at least 15 were managed originally by one of these lines of treatment. It would be too easy to blame this line of management, however, as we know of two patients who were treated initially with intermittent catheterisation.

Dr Hicks et al. have demonstrated the presence of Nitrosamines in infected human urines when studying patients with carcinoma of the bladder from Stoke Mandeville Hospital and also patients with schistosomiasis of the bladder. Although not proven, Nitrosamines may be important in the aetiology of carcinoma of the bladder in these patients.

The tumours encountered in patients with cord injury differed strikingly from those seen in the general population by the high incidence of squamous carcinoma and of the anterior site. Also three of these tumours involved the suprapubic. track. The fact that these tumours are so lethal in our patients may well be related to the delay of diagnosis.

Can these patients be diagnosed earlier? Cytology of the urine is unreliable in the presence of infection. As most patients presented with haematuria or other lower tract symptoms the development of these symptoms in anyone Io years or more after the onset of paralysis should suggest a bladder tumour. Cystoscopy and biopsy should be performed without delay. 


\section{SUMMARY}

Twenty-five patients with carcinoma of the bladder were found in a series of 6744 paraplegic and tetraplegic patients. The incidence of carcinoma of the bladder is at least 20 times higher than in the general population. There is no difference in the incidence between flaccid and spastic neurology below the level of the lesion. Most of these tumours were invasive and histologically 44 per cent were squamous, the anterior wall being involved in 25 per cent of the cases. The prognosis was poor. We advocate vigilant investigation of the urinary tract including cystoscopy and biopsy in patients with spinal cord injury complaining of haematuria.

\section{RÉSUMÉ}

On a trouvé 25 patients avec cancer de la vessie dans une population de 6744 paraplegiques. L'incident du cancer de la vessie est 20 fois plus élevé que dans la population generale. Il n'y avait pas de difference d'incidant entre la neurologie flaccide au spastique. La plupart des tumoures e'taicent invasive et $44 \%$ étaient du type quameux. Le mur antereur e'tait affecte dans $25 \%$ des cas. Le prognostic etait affreux. L'investigations vigilante du systeme urinaire avec cystoscopie et biopsie est recommandée chez les paraplegique et tetraplegique avec haematurie.

\section{ZUSAMMENFASSUNG}

Unter 6744 para-oder tetraplegischen Patienten wurden 25 Patienten mit einem Harnblasenkarcinom entdeckt. In der Patienten gruppe ist die Hä ufigkeit von Blasenkarcinomen mindistens 20 mal grösser als in der normalen Bevolkerung.

Das Tumor-Vorkommen ist gleich bei Patienten mit schlaffer oder spastischer Lähmun. Die meisten Tumoren waren invasive Tumoren and $44 \%$ waren histologisch vom Squamösen Typ. In $25 \%$ der Fälle war die vordere Blasenwand betroffen. Die Prognose war schlecht. Wenn Patienten mit Querschnittslähmung Zeichen von Hämaturie zeigen, sollte deshalb immer eine sorgfältige Abklärung des Harnwegstraktes (eischliesslich Zystoskopie und Biopsie) erfolgen.

\section{REFERENCES}

BRISTOL BLAdDER TUmour Registry-British fournal of Urology. I969.

Hicks, R. M. et al. (1978). International Atomic Research Council Scientific Publications, I9, 465-475.

Kawaichi, S. (I96I). Proceed. Ninth Ann. Clin. Cord Injury Conf., pp. I04-I05.

Melzak, J. (1966-67). Paraplegia, 4, 85-96.

Turner, A. (I980). Personal Communication. 